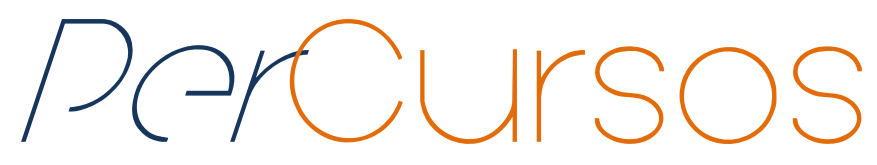

\title{
A realidade de risco de movimentos de massa em Petrópolis, RJ: uma contribuição da Educação Ambiental para a Proteção Civil
}

\begin{abstract}
Resumo
O presente trabalho visa discorrer sobre a realidade das pessoas moradoras de áreas de risco no município de Petrópolis-Rj e como a educação ambiental crítica pode vir a favorecer na prevenção de desastres naturais, relacionados aos movimentos de massa, que afetam fortemente a população mais vulnerável. Em parceria com a Escola Municipal Stefan Zweig, localizada na comunidade Amazonas, Bairro Quitandinha, $1^{\circ}$ distrito de Petrópolis, uma das mais afetadas pelos movimentos de massa, desenvolveu-se atividade didática para sala de aula na forma de oficina. Esta teve como público-alvo alunos do $9^{\circ}$ ano e contou com a participação do professor responsável pela disciplina de geografia, bem como da coordenação da escola. A etapa de elaboração e planejamento da atividade baseou-se em princípios da educação ambiental, com o objetivo de contribuir para a proteção civil dos estudantes dessa escola. Compreendemos que estes desastres naturais são frutos da distribuição desigual do espaço, tratando-se de uma injustiça ambiental, sendo necessário contextualizar estes riscos na realidade local, visando o estímulo na reflexão crítica contra a exposição desigual dos riscos e favorecendo a criação de uma cultura de proteção civil.
\end{abstract}

Palavras-chave: Educação Ambiental. Movimentos de Massa. Desastres Naturais. Injustiça Ambiental. Proteção Civil.

\section{Cristiane Oliveira Ferreira}

Mestranda em Geografia na Univ. Federal Rural do Rio de Janeiro UFRRJ. Professora Tutora do CEDERJ - UFRRJ.

Brasil

titi.geo@hotmail.com

\section{Edileuza Dias de Queiroz}

Mestre em Educação pela

Universidade Federal Rural do

Rio de Janeiro - UFRRJ e

Doutoranda em Geografia na

Universidade Federal Fluminense

- UFF. Professora da UFRRJ.

Brasil

edileuzaqueiroz@gmail.com

\section{Monika Richter}

Doutora em Geografia pela Univ. Federal do Rio de Janeiro - UFRJ.

Professora da UFRRJ.

Brasil

mrichter84@hotmail.com

\section{Para citar este artigo:}

FERREIRA, Cristiane Oliveira; QUEIROZ, Edileuza Dias de; RICHTER, Monika. A realidade de risco de movimentos de massa em Petrópolis, RJ: uma contribuição da Educação Ambiental para a Proteção Civil. Revista PerCursos, Florianópolis, v. 18, n.36, p. 34 - 65, jan./abr. 2017.

\section{DOI: 10.5965/1984724618362017034}

http://dx.doi.org/10.5965/1984724618362017034 


\title{
The reality of mass movements risk in Petrópolis, RJ: a contribution of Environmental Education to Civil Protection
}

\begin{abstract}
This paper aims to discuss the reality of people living in risky areas in the municipality of Petrópolis-Rj and how critical environmental education can favor the prevention of natural disasters related to mass movements that strongly affect the most vulnerable population. In partnership with the Stefan Zweig Municipal School, located in the Amazonas community, BairroQuitandinha,1st district of Petrópolis, one of the most affected by the mass movements, didactic activity was developed for classroom in the form of workshop. The target audience was 9 period students and was attended by the teacher, as well as the coordination of the school. The stage of elaboration and planning of the activity was based on principles of environmental education, with the objective of contributing to the civil protection of the students of this school. We understand that these natural disasters are the result of an unequal distribution of space, which is an environmental injustice, and it is necessary to contextualize these risks in the local reality, aiming at stimulating critical reflection against unequal exposure of risks and favoring the creation of a culture of civil protection.
\end{abstract}

Keywords: Critical Environmental Education. Mass Movements. Environmental Natural Disaster. Environmental Injustice. Civil Protection. 


\section{Introdução}

A demanda social por uma educação que abarque as questões ambientais muito tem crescido nas últimas décadas, visando auxiliar na solução dos crescentes problemas socioambientais como a poluição, desmatamento e desastres naturais agravados pela ação humana. Os meios acadêmico, científico e os movimentos sociais integraram em suas pautas de debate as questões ambientais, assim a educação ambiental emerge nos locais formais e informais de ensino e aprendizagem.

Baseado em Castro (1999, p. 8), considera-se Desastre o "resultado de eventos adversos, naturais ou provocados pelo homem sobre um ecossistema vulnerável, causando danos humanos, materiais e ambientais e consequentes prejuízos econômicos e sociais." Visando compreender melhor estes fenômenos desastrosos, o autor também afirma que podemos classificá-los de acordo com sua origem como desastres naturais, desastres humanos (ou antropogênicos) ou desastres mistos.

Desastres naturais são aqueles produzidos por fenômenos e desequilíbrios da natureza. Por este motivo, independem da ação humana, como furacões e erupção vulcânica. Já os desastres humanos são resultado da ação ou omissão humana e estão intimamente relacionados às atividades humanas, enquanto agente ou ator. Porém,

A tendência moderna é considerar que, na sua grande maioria, os desastres, hoje classificados como naturais ou antrópogênicos, na realidade são mistos. No momento atual, são considerados desastres mistos aqueles que resultam da soma interativa de fenômenos naturais com atividades humanas. Essas interações, por seu aspecto globalizante, tendem a alterar profundamente os ecossistemas naturais e humanos, afetando, às vezes, grandes extensões do meio ambiente. (CASTRO, 1999, p. 9)

A educação ambiental pode contribuir como fomentadora de reflexões e ações dos atores envolvidos em realidades vulneráveis aos desastres. Segundo Layrargues e Lima (2011), existem três macrotendências como modelos político-pedagógicos para a educação ambiental: conservadora, pragmática e crítica. Para essa pesquisa foi escolhida a vertente crítica que se dedica a compreender as causas e efeitos dos problemas 
socioambientais. Por este motivo, é essencial a contextualização social e política dos fenômenos nas diversas escalas. Além de questionar as contradições do modelo de desenvolvimento capitalista dominante, que produz a exploração da natureza e dos seres humanos em prol do capital. Portanto, é politicamente comprometida, visando à superação das injustiças socioambientais.

Desta forma,

Apoia-se com ênfase na revisão crítica dos fundamentos que proporcionam a dominação do ser humano e dos mecanismos de acumulação do Capital, buscando o enfrentamento político das desigualdades e da injustiça socioambiental. (LAYRARGUES; LIMA, 2011, p. 11)

Guimarães (2004) corrobora com esta ideia, ao afirmar que:

A educação ambiental crítica das desigualdades sociais e dos desequilíbrios nas relações entre sociedade e natureza percebe os problemas ambientais como decorrentes do conflito entre interesses privados e coletivos, mediados por relações desiguais de poder que desestruturam a sociedade contemporânea em suas múltiplas determinações e seu modo de produção. (GUIMARÃES, 2004, p. 75)

Assim, para estudar o risco de movimento de massa ${ }^{1}$ no contexto escolar, essa perspectiva da educação ambiental se mostra como uma ferramenta importante, tendo em vista que a temática necessita da interlocução entre questões físicas, ligadas às ciências naturais, e às dinâmicas socioculturais aprofundadas nas ciências sociais.

Nesta compreensão, não é possível pensar na segurança da população moradora de áreas de risco sem se levar em consideração as dinâmicas socioculturais, a interrelação entre o meio físico e os seres humanos e as percepções ambientais destas

\footnotetext{
${ }^{1}$ Segundo Tominaga (2015, p. 27) "é o movimento do solo, rocha e/ou vegetação ao longo da vertente sob ação direta da gravidade. A contribuição de outro meio, como água ou gelo se dá pela redução da resistência dos materiais de vertente e/ou pela indução do comportamento plástico e fluido dos solos..."
} 
pessoas. Desta forma, é necessário, então, considerar a interface entre a natureza e a sociocultura.

\section{Vulnerabilidade e Injustiça Ambiental}

Cada grupo social possui características próprias, com potencialidades e dificuldades diferentes. Por este motivo, ao se pensar em Riscos², devemos levar em consideração que cada evento pode afetar negativamente populações distintas de formas também diferenciadas.

Quando provocamos uma perturbação, a resposta do meio pode ser bastante diferente em função das características locais naturais e humanas, ou seja, cada fração de território tem uma condição intrínseca que, em interação com o tipo e magnitude do evento que induzimos, resulta numa grandeza de efeitos adversos. A essa condição chamamos de vulnerabilidade (SANTOS; CALDEYRO, 2007, p. 18).

Há diversos fatores que indicam se determinados grupos da sociedade estão mais propensos do que outros à perda, ao dano e ao sofrimento no contexto de diferentes ameaças, tais como idade, gênero, etnia, incapacidade, classe ou status social, casta e pobreza (ALMEIDA, 2012, p. 34).

A lógica de acumulação capitalista permite que os recursos naturais básicos para a sobrevivência sejam transformados em mercadoria. Assim, o solo, a terra, pode ser comprada/vendida de acordo com os interesses econômicos e o capital disponível para tal transação.

Os movimentos de massa, que afetam constantemente a Região Serrana do estado do Rio de Janeiro, são ótimos exemplos de como os desastres naturais podem

\footnotetext{
${ }^{2}$ Risco é a probabilidade de ocorrer consequências danosas ou perdas esperadas (mortos, feridos, edificações destruídas e danificadas, etc.), como resultado de interações entre um perigo natural e as condições de vulnerabilidade local (UNDP, 2012). Dagnino e Carpi Junior (2007, p. 50) consideram que a "definição de risco ambiental é formada por uma fusão das noções aceitas popularmente, em que se une a percepção das pessoas com os conceitos já estabelecidos na literatura sobre o tema. Assim, abre-se espaço para aplicar e adaptar os conceitos conforme as características de cada pesquisa e/ou dos objetivos pedagógicos de cada atividade."
} 
afetar diferentemente as pessoas de acordo com suas condições financeiras, que são determinadas pelas desigualdades socioeconômicas.

Para as pessoas de baixa renda há uma grande dificuldade em adquirir moradias fora das áreas de risco e, ao mesmo tempo, construir uma edificação com estruturas mais resilientes, capaz de resistir aos eventos adversos. Neste sentido, pode-se analisar a situação das moradias em áreas de risco de movimentos de massa, fruto desta racionalidade da modernização. Conforme as cidades crescem, com foco no desenvolvimento do capital, a população pobre sofre mais fortemente com os danos provocados por esta lógica.

Um marco clássico na paisagem urbana, que reflete esta racionalidade, são as favelas. Estas, comumente, ocupam as áreas desvalorizadas pelo capital, como próximo aos rios, vertentes de morros, antigos lixões, locais próximos às fabricas poluentes e depósitos de resíduos tóxicos. Cada um destes ambientes expõem as pessoas a diferentes riscos, portanto cabe ao educador ambiental analisar a realidade e problematizá-la. Neste sentido, Tristão (2002) destaca quatro desafios associados ao papel do educador ambiental: o educador precisa fazer conexões, identificar e compreender as interpretações relacionadas ao meio ambiente; promover a ruptura da visão de especialidades; pensar nos riscos produzidos e nas incertezas científicas; e na necessidade de superação das desigualdades sociais.

Beck (2011) afirma que na atualidade estamos inseridos em uma Sociedade de Risco, ou seja, todos os seres humanos estão envolvidos em diversos riscos em seu cotidiano, principalmente por aqueles criados pela modernidade, como poluição, exposição nuclear, entre outros. Isto significa que estes riscos também afetam aqueles responsáveis por produzi-los, portanto esta sociedade de risco não é, necessariamente, uma sociedade de classe, porém,

Isso não anula o fato de que muitos riscos sejam distribuídos de um modo especificado pela camada ou pela classe social. A história da distribuição dos riscos mostra que estes se atêm, assim como as riquezas, ao esquema de classes - mas de modo inverso: as riquezas acumulam-se 
em cima, os riscos embaixo. Assim, os riscos parecem reforçar, e não revogar, a sociedade de classes. (BECK, 2011, p. 41)

No caso das moradias em áreas de risco de movimento de massa, a prática da autoconstrução merece destaque. Esta forma de se garantir a infraestrutura básica para a sobrevivência contribui para a alteração da dinâmica natural, como por exemplo, corte de taludes, retirada da vegetação local, entre outros, agravam a erosão em casos de eventos adversos como chuvas intensas, fragilizando ainda mais as estruturas dessas autoconstruções.

A desigualdade intrínseca à sociedade contemporânea permanece diretamente relacionada à ocupação das áreas de risco. Gould (2001) afirma que distribuição dos riscos ambientais por classe social é uma consequência normal das economias capitalistas. Assim, seguindo a lógica imobiliária, apenas as pessoas com capital suficiente podem adquirir residências em áreas mais seguras. Enquanto, uma grande parcela das pessoas deve se adequar às áreas que não são de interesse do mercado, que normalmente são as que apresentam maior risco.

Cabe destacar que os grupos socialmente excluídos também são modeladores do espaço urbano, sendo a ação espacial independente dos demais agentes. Corrêa (2000, p. 30) afirmar que "resistência e sobrevivência se traduzem na apropriação de terrenos usualmente inadequados para os outros agentes da produção do espaço, tais como encostas íngremes e áreas alagadiças."

Desta forma, as injustiças se tornam evidentes. Na realidade brasileira, os interesses privados têm sido postos acima dos públicos, ao mesmo tempo, há uma negligência por parte do Estado em garantir à população acesso a direitos básicos, como a moradia segura, acarretando a injustiça ambiental. Compreende-se injustiça ambiental como:

O mecanismo pelo qual sociedades desiguais, do ponto de vista econômico e social, destinam a maior parte dos danos ambientais do desenvolvimento às populações de baixa renda, aos grupos sociais discriminados, aos povos étnicos tradicionais, aos bairros operários, as populações marginalizadas e vulneráveis. (REDE BRASILEIRA DE JUSTIÇA AMBIENTAL, 2001, p. 1) 
Assim, os riscos de movimentos de massa são maiores para as pessoas mais vulneráveis, devido principalmente ao perfil socioeconômico da população moradora dessas áreas e omissão por parte do poder público em seu papel de orientação, monitoramento e fiscalização. Ou seja, esta realidade ocorre tanto por consequências da lógica capitalista de desenvolvimento da cidade e de apropriação do solo, como pela estratégica omissão do Estado.

\section{Educação Ambiental crítica e a aproximação com a realidade do risco}

Perante estas problemáticas socioambientais, a educação ambiental crítica pode contribuir para estimular os estudantes a refletirem sobre a realidade complexa que os cerca. Objetivando a superação das injustiças socioambientais, são necessárias mudanças profundas na sociedade contemporânea, na qual esta educação pode contribuir por desvelar as questões centrais.

É importante destacar que a educação ambiental escolar "deve adotar uma abordagem que considere a interface entre a natureza, a sociocultura, a produção, o trabalho, o consumo, superando a visão despolitizada, acrítica, ingênua e naturalista ainda muito presente na prática pedagógica das instituições de ensino” (Brasil, 2012, p. 2).

Desta forma, os riscos ambientais são ótimas questões para serem trabalhadas no contexto escolar, tendo em vista que para a sua compreensão é necessária uma profunda reflexão sobre diversas questões da nossa sociedade. No entanto, a fragmentação que ocorre dentro das próprias ciências inseridas na escola, como na Geografia, os conhecimentos necessários para a compreensão da realidade usualmente são transmitidos para os estudantes de forma desconexa com a realidade e isolados em tópicos específicos de um determinado bimestre ou ano escolar. Esta característica implica na dificuldade dos estudantes em entenderem a realidade complexa do mundo atual e da exposição aos riscos. Portanto, os educadores devem buscar esforços para contextualizar a realidade na qual o estudante está inserido com os conceitos abstratos trabalhados durante as aulas. 
Ao trabalhar os riscos ambientais é necessário interligar as diversas ciências como Geografia, Sociologia, Filosofia, Física, Química, entre outras. Portanto, o educador ambiental necessita estimular a interdisciplinaridade na escola.

A Política Nacional de Educação Ambiental instituída pela Lei nº 9.795, de 1999 estabelece em seu art. $2^{\circ}$ que "a educação ambiental é um componente essencial e permanente da educação nacional, devendo estar presente, de forma articulada, em todos os níveis e modalidades do processo educativo, em caráter formal e não-formal". No entanto, embora a sua inquestionável relevância, cabe destacar a recente alteração no artigo 26 da LDB e, consequentemente, em seu parágrafo 7 (inserido anteriormente pela lei 12.608/12), excluindo a obrigatoriedade dos princípios da proteção e defesa civil e a educação ambiental de forma integrada aos conteúdos obrigatórios no ensino fundamental e médio.

O sistema educacional brasileiro abrange todos os anos uma grande quantidade de cidadãos, portanto as escolas podem e devem auxiliar para que a população tenha maior entendimento sobre os riscos ambientais aos quais é exposta e qual a melhor forma de conviver e lidar com eles, além da criação de uma cultura nacional de proteção civil. A união que é feita pela lei entre a educação ambiental e os princípios da proteção e defesa civil, demonstrava que estes conhecimentos podem ser trabalhados em conjunto e de forma integrada perante as realidades de risco no território brasileiro.

A educação ambiental representará importante ferramenta para a construção da cultura de proteção civil, tendo em vista que a convivência com o risco é uma realidade da população local.

Neste sentido,

A principal função do trabalho com o tema Meio Ambiente é contribuir para a formação de cidadãos conscientes, aptos a decidir e atuar na realidade socioambiental de um modo comprometido com a vida, com o bem-estar de cada um e da sociedade, local e global. (BRASIL, 1997) 
Para analisar a realidade local é importante que o estudante a observe com um olhar investigativo, com outra perspectiva, além do usual que ocorre no seu dia a dia. Para isso, existem recursos didáticos que podem ser utilizados tais como os trabalhos de campo, a construção de maquetes, desenhos, entre outros.

Outra aproximação possível com a realidade dos estudantes que pode ser trabalhada pelos professores é através de reportagens, fotos, charges, dentre outros recursos metodológicos, porém sempre de forma problematizada. Sendo de baixo custo e fácil transporte, estes materiais podem ser utilizados para abordar temas atuais dentro das disciplinas escolares.

O importante é sempre manter uma relação entre a escola e o mundo. Isso pode ocorrer tanto levando os estudantes para fora da escola, estimulando uma visão de pesquisadores ou trazendo o mundo para dentro dos muros das escolas, por meio de questionamentos feito pelos professores, por diferentes mídias ou outras linguagens.

Esta tentativa de levar os estudantes a serem mais críticos e participativos na comunidade sobre a realidade atual é, em si, uma mudança significativa de lógica educacional. O que tem se buscado por políticas de Estado, por avaliações verticais, por criação de ranking de "melhores escolas" é a competição e preparação dos estudantes apenas para o mercado de trabalho, desconsiderando a formação completa de seres humanos e cidadãos, capazes de atuar na construção de um futuro mais justo e sustentável.

A respeito disso, as Diretrizes Curriculares Nacionais de Educação Ambiental (Brasil, 2012, p. 3) afirmam que a educação ambiental deve ser comprometida com a construção de sociedades "fundadas nos valores da liberdade, igualdade, solidariedade, democracia, justiça social, responsabilidade, sustentabilidade e educação como direito de todos e todas."

Guimarães (2004, p. 48) corrobora com a legislação acima citada, ao afirmar que, “(...) a EA crítica volta-se para uma práxis de transformação da sociedade em busca de uma sustentabilidade calcada em novos paradigmas, condições materiais, posturas éticopolíticas, entre outros." 
Para alcançar a sustentabilidade é necessária a superação das injustiças sociais e ambientais. Assim, o movimento pela Justiça Ambiental defende que nenhum grupo suporte de forma desproporcional as consequências ambientais negativas de operações econômicas e de decisões de políticas (ACSELRAD; HERCULANO; PÁDUA, 2004).

Mas, para esta justiça ambiental se concretizar é necessária uma mudança da lógica de produção e exploração do meio, ou seja, a construção de um novo paradigma. Isso só é possível se a educação se assumir como um dos movimentos de resistência ao paradigma dominante, de forma que prepare os estudantes para lutarem por padrões de vida mais sustentáveis e justos, primeiramente em nível local, se expandindo para o global.

\section{A realidade de risco de deslizamentos de terra em Petrópolis/RJ}

O município de Petrópolis (figura 1), localizado na Região Serrana do estado do Rio de Janeiro, é conhecido por suas belezas naturais e história, sendo popularmente chamado de Cidade Imperial, pois foi fundado no século XIX com o objetivo de atender D. Pedro Il e a nobreza do império.

Segundo o IBGE (2010), a área total do município é de 795,8 quilômetros quadrados, correspondendo a $11,5 \%$ da Região Serrana do estado do Rio de Janeiro. A figura 1, abaixo, destaca a localização de Petrópolis. 


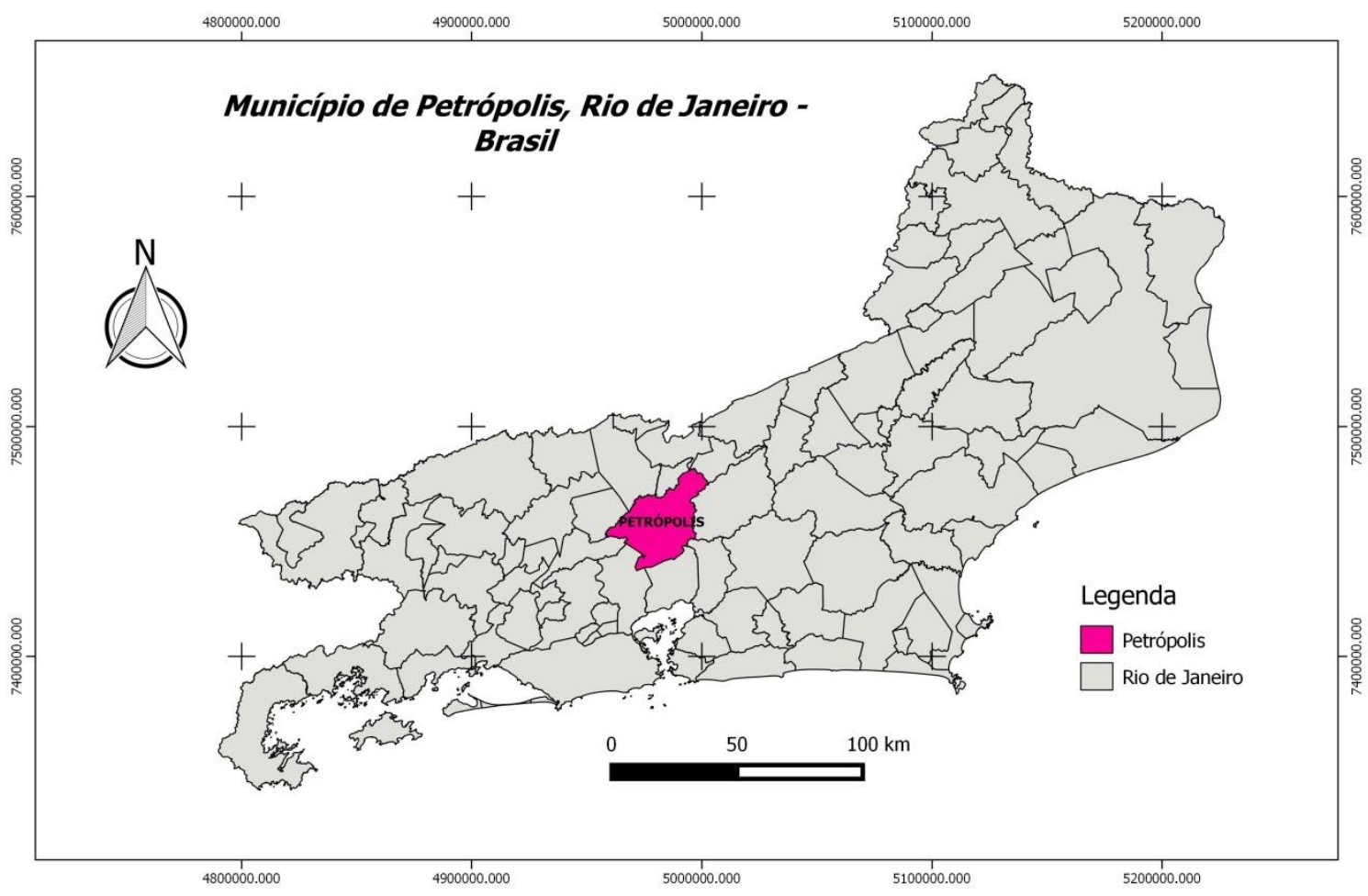

Figura 1 - Localização de Petrópolis. Fonte: Dados do IBGE. Produzido por Cristiane Oliveira Ferreira - Software Qgis.

Esta região começou a ser fortemente ocupada em 1843, quando, por ordem de D. Pedro II, o engenheiro alemão Júlio Frederico Koeler construiu um Palácio de verão e uma nova estrada para a subida da Serra. No ano seguinte, foi criado o distrito de Petrópolis, na freguesia de São José do Rio Preto, município de Paraíba do Sul. Koeler planejou toda a cidade a fim de abastecer as necessidades da nobreza, focando na produção agrícola. Nesta época, houve um grande fluxo migratório de alemães para a região a fim de trabalharem na agricultura local (RIO DE JANEIRO, 2013).

Gregório (2014) destaca que os descendentes de alemães dinamizaram a economia da cidade no início da república com a produção têxtil. Neste sentido, Petrópolis apresentou um "boom” econômico entre os anos de 1940 e 1950 em função da grande expansão da industrialização, estimulada pelos investimentos do governo no setor, como também pela presença de grandes empresários e artesãos no município. 
Foi neste processo que as encostas do município começaram a ser ocupadas. O sítio geográfico pequeno em área, e a necessidade da população em morar próximo ao mercado de trabalho, contribuíram para a urbanização de áreas inadequadas às moradias, fugindo do planejamento territorial inicial.

A população total em 1945 era de 84.875 habitantes; o Censo Demográfico realizado pelo Instituto Brasileiro de Geografia e Estatística neste mesmo ano afirma que 10.609 pessoas trabalhavam na indústria extrativista ou de transformação na cidade diretamente, o que correspondia a aproximadamente $12,5 \%$ da população somente no ano de 1940 (IBGE, 1948).

A reestruturação produtiva industrial brasileira, por volta dos anos 1970, fez com que as indústrias petropolitanas não conseguissem concorrer com as demais nacionais, gerando um grande número de falências, o que acarretou o crescente desemprego no município. Assim, faz-se importante elucidar que “(...) nenhuma política foi feita para reordenar a urbanização nem fornecer alternativas espaciais e de emprego à população menos favorecida" (Gregório, 2014, p. 8).

Em 2010, o IBGE calculou a população municipal em 295.917 habitantes, sendo que a população economicamente ativa corresponde a 139.505 habitantes (IBGE, 2010). Porém, cabe destacar que o número total de empregos formais no município registrados em janeiro de 2017, pelo Ministério do Trabalho e Emprego foi de 66.967. Assim, pode-se observar que uma parcela significativa da população local não tem disponibilidade de emprego em seu próprio município.

Atualmente, a indústria é responsável pela geração de 13.745 empregos formais, porém, apesar do número absoluto ter aumentado em relação a 1940, o valor só corresponde a aproximadamente $4.6 \%$ da população municipal. Enquanto o setor de comércio e serviços emprega 46.893 pessoas (15,8 \% da população municipal).

Assim, pode-se notar que a economia municipal foi drasticamente alterada desde o declínio da industrialização. O setor secundário perdeu importância e o setor de comércio e serviços ganhou destaque como principal fonte de renda da população. 
Petrópolis possui uma dinâmica urbana complexa, que merece destaque. Como boa parte da população busca emprego ou estudo fora da cidade, é importante ressaltar a forte ligação que o município possui com a metrópole do Rio de janeiro. Castello Branco (2006, p. 7), ao buscar a delimitação do Espaço Urbano do Rio de Janeiro, destacou o seguinte: “(...) ocorre que Petrópolis se acha diretamente vinculada à metrópole carioca para onde se dirige a maior parte dos seus fluxos (...).”

Randolph (2005) salienta que Petrópolis e a cidade do Rio e Janeiro possuem ligações fortes criadas ao longo da historia, e que permanecem até os dias atuais. Apesar disto, o município foi retirado da Região Metropolitana do Rio de Janeiro, por volta de 1990, por decisão política local, passando a fazer parte da Região Serrana.

Esta região possui encostas íngremes, clima tropical de altitude com a presença de precipitação em todos os meses do ano e a inexistência de estação seca. A região é muito suscetível aos movimentos de massa naturais e, a ocupação das encostas, o desmatamento, alterações no ambiente em geral agravam a problemática, configurando assim um risco aos bens materiais e vidas humanas (GUERRA, GONÇALVES e LOPES, 2007; BRASIL, 2005; E GALVANI, 2014).

O Atlas Brasileiro de Desastres Ambientais (1991-2012) produzido pela CEDEP/UFSC (2013) salienta que no Brasil, apenas no período de 1991 a 2012, foram registrados 38.996 desastres, os quais afetaram em torno de 1,5 milhão de cidadãos. As estiagens e secas são os desastres que mais impactaram pessoas no território nacional, seguidos pelas enxurradas e inundações. Porém, os movimentos de massa são a segunda maior causa de morte em desastres.

No período acima, foram registrados 699 movimentos de massa no Brasil, sendo 153 apenas no estado do Rio de Janeiro. Em relação à mortalidade nestes eventos, foram 535 no país e 418 ocorreram apenas no RJ, totalizando 79,8 \% das ocorrências (CEDEP/UFSC, 2013).

Dentro do estado do Rio de Janeiro, ainda considerando os desastres decorrentes de movimentos de massa pelo CEPED/2013, Petrópolis se destaca, pois no período de tempo analisado, o município foi o mais atingido, com um total de 18 registros oficiais. 
Esta realidade está fortemente ligada às características ambientais e condicionantes sociais do município.

Os desastres naturais registrados no município de Petrópolis foram significativos, com destaque para os anos de 2001, 2011 e 2013, quando ocorreram 146 mortes confirmadas segundo dados Brasil (2017) e danos econômicos.

Quanto à população local, deve-se destacar que a renda é diversificada, porém uma porcentagem significativa dos domicílios possui renda média abaixo de dois salários mínimos, como na figura 2 abaixo.

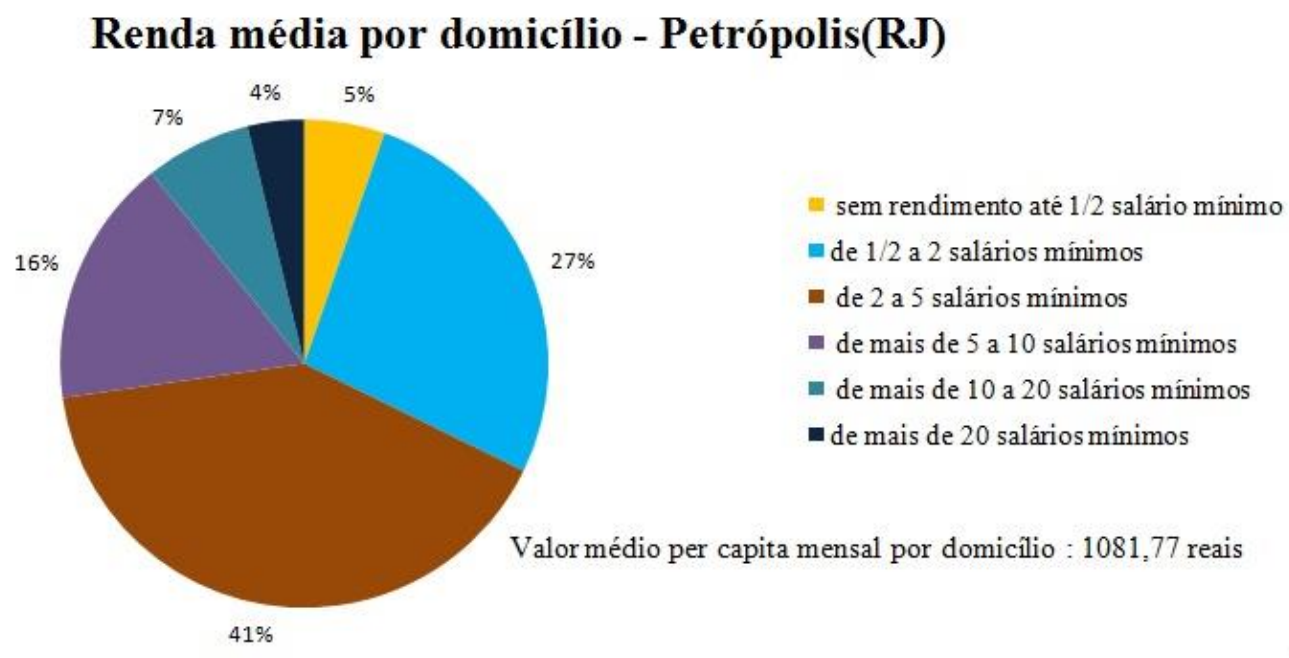

Figura 2 - Renda média da população. Fonte: IBGE, Censo Demográfico 2010.

Além da dificuldade de empregos e a baixa renda, há outros fatores que dificultam a aquisição de moradias em áreas seguras pela população, tais como a especulação imobiliária e o legado histórico em relação à ocupação e domínios das terras da região.

A especulação imobiliária é um fenômeno que tem aumentado nas últimas décadas e que tem afetado diretamente a população petropolitana. Devido a sua vocação turística e às características ambientais encontradas, como ar mais limpo, grande reserva de água, vegetação e clima ameno, o município tem sido alvo de empreendimentos de segunda residência, o que encarece o valor dos imóveis. 
Outro fator que dificulta a compra de residências legalizadas é o laudêmio, correspondente a uma cota de $2,5 \%$ do valor de qualquer transação de compra e venda de imóveis que deve ser paga aos descendentes da família imperial que ainda residem na cidade. A cobrança desta taxa faz com que as residências fiquem ainda mais caras. Desta forma, apenas uma pequena parcela da população dispõe de condições financeiras para habitar áreas de menor risco.

Assim, a "Cidade Imperial”, primeira a ser planejada na América Latina (Gregório, 2014), durante sua história, manteve a essência do projeto, tendo as classes dominantes ocupando os vales, mais seguros para se habitar, apresentando inclusive melhores condições de infraestrutura urbana enquanto os mais pobres passaram a ocupar áreas expostas aos maiores riscos, como encostas dos morros e as margens dos rios.

Ao compreender que a exposição de determinado grupo de pessoas aos riscos está diretamente relacionada às consequências da lógica capitalista, pode-se dizer que há um quadro de Injustiça Ambiental intimamente relacionada aos desastres naturais, decorrentes tanto da omissão do poder público quanto da falta de fiscalização e orientação aos moradores a respeito da distribuição desigual de poder e das desigualdades socioeconômicas.

\section{Locus da Pesquisa - breve caracterização}

A pesquisa foi aplicada na Escola Municipal Stefan Zweig, que está inserida no bairro Quitandinha, localizado no $1^{\circ}$ distrito de Petrópolis. A escolha dessa área é devido à grande vulnerabilidade socioambiental da população e por ser uma das áreas mais afetadas pelos recorrentes deslizamentos de terra no município.

Segundo o Plano Municipal de Riscos, elaborado em 2007 pela empresa THEOPRATIQUE, no bairro Quitandinha, existem 15 áreas de risco, sendo três presentes no recorte geográfico de interesse desta pesquisa devido as suas características socioambientais. Os dados abaixo, delimitados em regiões, retirados do referido documento, demonstram a relevância desta comunidade para estudo (figura 03). 
Região Amazonas: Localizada ao sul da E.M. Stefan Zweig. Número total de moradias que necessitam de intervenção ultrapassa 410, sendo que destas, 100 apresentam um nível altíssimo de risco aos movimentos de massa. Região Bahia: Localizada a noroeste da E.M. Stefan Zweig. Possui 31 casas que necessitam de intervenções. Possui áreas de alto e médio risco. Região Cuba: Localizada a nordeste da E.M. Stefan Zweig. Pequena área com moradias localizadas próximas a um córrego, em local desprovido de urbanização e infraestrutura. Apresenta áreas de médio risco.

A figura 3 mostra o entorno da Escola Stefan Zweig, local de aplicação da oficina.

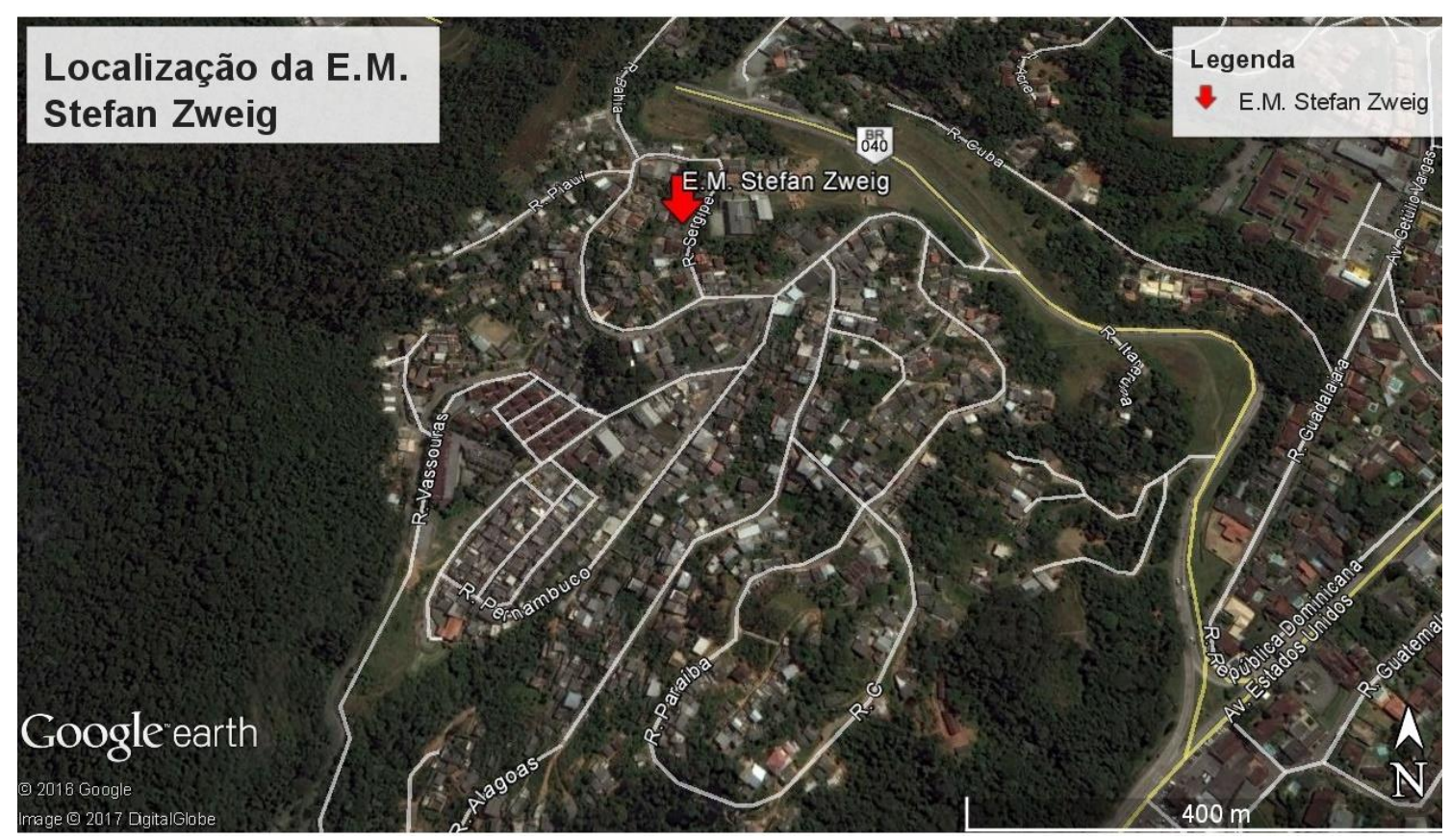

Figura 3 - Localização da E. M. Sfetan Zweig e seu entorno. Fonte: Google Earth, 2017.

Em escala de detalhe (Figura 04) é possível notar as construções precárias, assim como a infraestrutura de acesso, muitas sem nenhum tipo de pavimentação. 


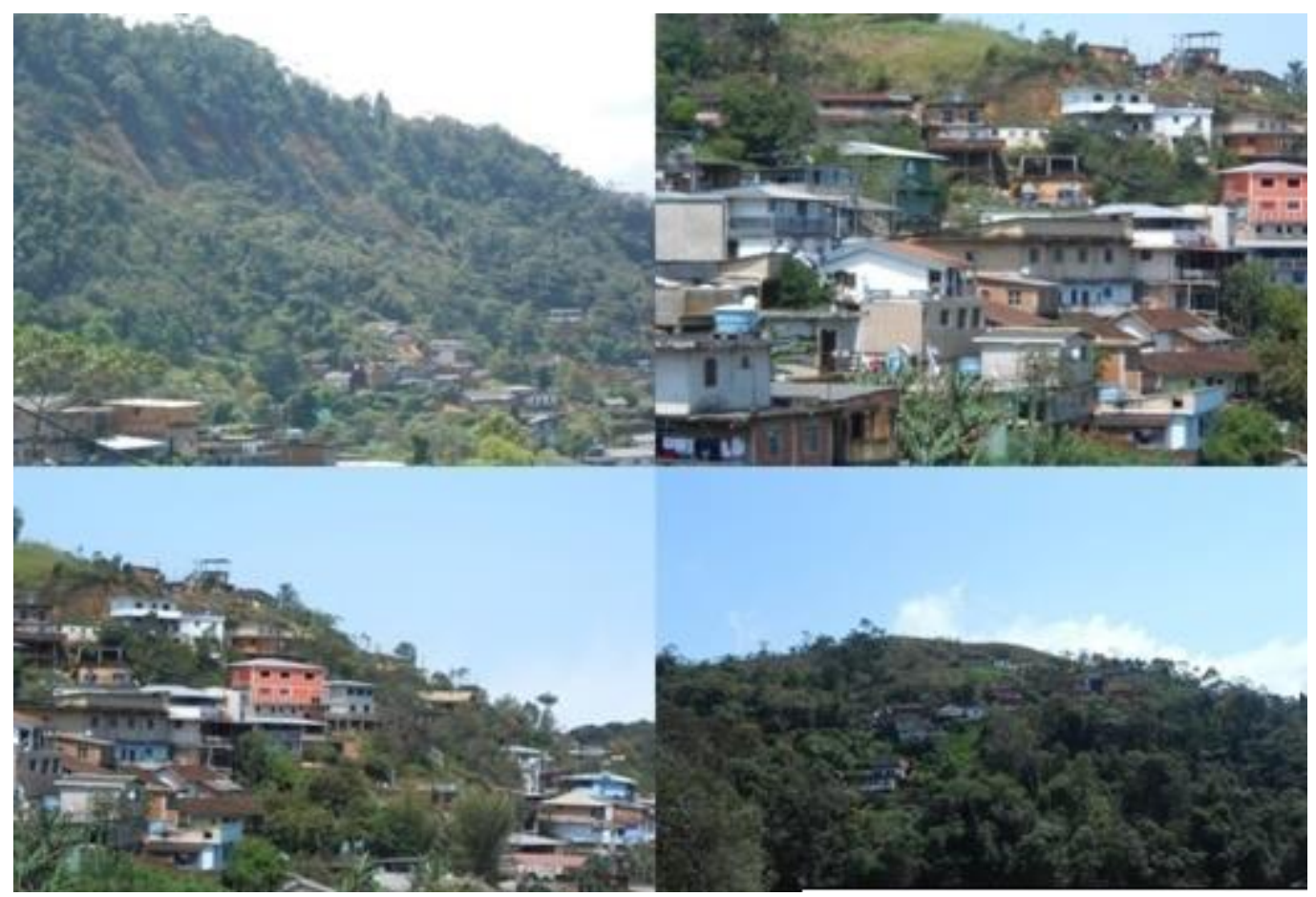

Figura 4 - Áreas de risco no entorno da E.M. Stefan Zweig. Fonte: Cristiane O. Ferreira. Jun. 2015.

As intervenções citadas no plano para estas regiões abrangem ações estruturais, tais como remoções, melhorias estruturais, infraestrutura de drenagem ou contenção, urbanização, reflorestamento e saneamento básico.

A escola na qual a pesquisa foi aplicada atende 469 estudantes provenientes do seu entorno. Estes alunos estão distribuídos nos turnos da manhã e da tarde. A instituição de ensino também é um ponto de apoio em caso de chuvas fortes e situações de emergência. Assim, caso as sirenes sejam acionadas, a população do entorno deve procurar abrigo dentro da escola.

A instituição foi escolhida para este estudo devido a sua inserção em uma área de grande risco de movimento de massa, segundo o Plano municipal de Risco, 2007. Além da equipe gestora se mostrar muito receptiva à pesquisa, deu total apoio e suporte para que ela fosse realizada. Diante desta realidade, percebe-se que é um ambiente propício para ser trabalhado em uma proposta de educação ambiental crítica. Hoje, se torna cada vez mais evidente a necessidade de mudar a realidade injusta nas diversas escalas espaciais, partindo da local. 
Como uma tentativa de prevenir e remediar os efeitos dos riscos ambientais no Brasil, a defesa civil possui um Ciclo de Redução de Riscos de Desastres (RRD), o qual abrange a redução do risco, o manejo do desastre e a recuperação do local afetado. Estas etapas são subdivididas em prevenção, mitigação, preparação, resposta e recuperação voltada à proteção e defesa civil. As medidas de mitigação, segundo Lima $\left(2015^{3}\right)$, "consistem em uma intervenção humana com o intuito de minimizar os riscos de desastres, reduzindo os possíveis impactos ao homem, a bens ou ao ambiente". Seria, então, a tentativa de minimizar os riscos até o ponto em que eles se tornem aceitáveis para que as pessoas possam conviver com o menor sofrimento possível caso ocorra um desastre.

Uma das medidas de mitigação mais importantes é a educação, que pode favorecer para a compreensão de uma realidade em que haja riscos ambientais e também a reflexão de suas causas e consequências através de uma educação significativa, de maneira que ajude a promover o desenvolvimento de cidadãos críticos e empenhados na construção de uma nova realidade, na qual as injustiças ambientais tenham sido superadas.

A população moradora de áreas de risco em Petrópolis é altamente vulnerável e necessita viver com os riscos, devido à injustiça ambiental. Assim, a convivência com os riscos deve ser enfrentada como uma condição séria, no qual é necessária a busca para a mitigação dos danos causados pelos deslizamentos de terra, sendo a educação um bom começo para esta transformação social. (FERREIRA, 2015, p. 47)

Baseado nos princípios da educação ambiental crítica, podem-se desenvolver atividades lúdicas que incorporem os conceitos e realidades de risco para serem debatidos no contexto escolar. Esta prática pode contribuir para a construção de conhecimentos significativos visando reduzir os dados de fatalidades ocorridos durante

\footnotetext{
${ }^{3}$ Autor da apostila "Redução de riscos de desastres - RRD", disponível para o $1^{\circ}$ Curso de Capacitação para Professores em Proteção e Defesa Civil, parte do Programa Escola Resiliente, feito em parceria entre a Prefeitura de Petrópolis e a Secretaria de proteção e defesa civil.
} 
um evento desastroso. Desta forma, os jovens podem estar mais preparados para agir de forma consciente em caso de perigo, visando à proteção da vida.

\section{Trabalhando os riscos em sala de aula - aspectos metodológicos}

Procurando analisar como a educação ambiental crítica pode contribuir diante da realidade de risco, realizou-se uma oficina intitulada "Os Riscos de deslizamentos de Terra em Petrópolis", no âmbito de uma pesquisa acadêmica iniciada na graduação e que, atualmente, desdobra-se na pós-graduação, no mestrado da primeira autora.

A oficina ocorreu no dia 6 de outubro de 2015, com cerca de 30 estudantes do $9^{\circ}$ ano do ensino fundamental. Esta atividade teve a duração de quatro horas e contou com a participação do professor responsável pelo desenvolvimento das aulas de geografia para a turma. E a atividade foi idealizada de forma a contemplar diferentes abordagens didáticas, tais como o uso de maquetes, gráficos, fotos e outros recursos com o objetivo de ser mais dinâmica e interativa para os estudantes e, desta forma, ser mais atrativa aos jovens.

A dinâmica em sala iniciou-se abordando a construção socioespacial do município de Petrópolis através de exposição de slides, contando com documentos cartográficos e fotos. Neste momento, o foco era a compreensão da transformação socioespacial ocorrida no município ao longo de sua história e como a ocupação das encostas está intrinsecamente relacionada aos ciclos econômicos locais, desnaturalizando a presença de moradias em áreas de risco. Houve destaque para a explicação do planejamento inicial feito por Koeler por volta de 1843; a industrialização de Petrópolis e a queda da economia industrial no município, as consequências espaciais e as dinâmicas econômicas e espaciais atuais.

Também se julgou necessária a caracterização do ambiente físico do município e a relação com os movimentos de massa, principalmente a dinâmica natural da erosão. Nesta etapa, priorizou-se o uso de desenhos e esquemas para ilustrar a explicação. 
Como proposta de interligar as questões sociais com os aspectos físicos relacionados aos deslizamentos de terra, foi utilizada uma maquete. Este recurso pode contribuir de maneira significativa, já que permite aos estudantes exporem sua visão da organização espacial e a visualização dos desastres, além de outras atribuições, como destaca Valencio, Siena, Marchezini (2009):

A miniaturização do território, cuja cena pode ser vista dinamicamente, é capaz, em primeiro lugar, de reproduzir tanto uma representação espacial de riscos, como a representação de ideais de organização quanto, ainda, várias interpretações de um mesmo desastre. Em segundo lugar, a construção e a desconstrução dos cenários resultam da negociação de sentidos entre os participantes, isto é, subsidia a comunicação verbal ao permitir que o interlocutor seja remetido à situação cuja interpretação almeja alcançar validação. (VALENCIO,SIENA,MARCHEZINI,2009, p. 203)

A maquete utilizada foi construía da seguinte forma: a base de caixa de leite Tetrapack, onde foi feita uma superfície inclinada com o poliestireno (isopor) para aparentar uma encosta rochosa. Na lateral da maquete, havia uma janela transparente projetada para permitir a visualização do processo erosivo.

Com a ajuda dos participantes foi acrescentada terra por cima da "rocha" para a representação da encosta com o solo. Também foram acrescentados elementos que fazem parte do espaço atual, como vegetação, casas (construídas com E.V.A) e áreas de solo exposto.

Após a montagem da maquete, com a ajuda de uma garrafa PET cheia de água com furos na tampa, a um dos estudantes solicitou-se que simulasse chuva sobre a maquete. Desta forma, representou-se um evento de forte precipitação, cujos efeitos da água no solo e nas residências ficaram claros, assemelhando-se ao processo de movimentos de massa, como observa-se na figura 5 abaixo. 


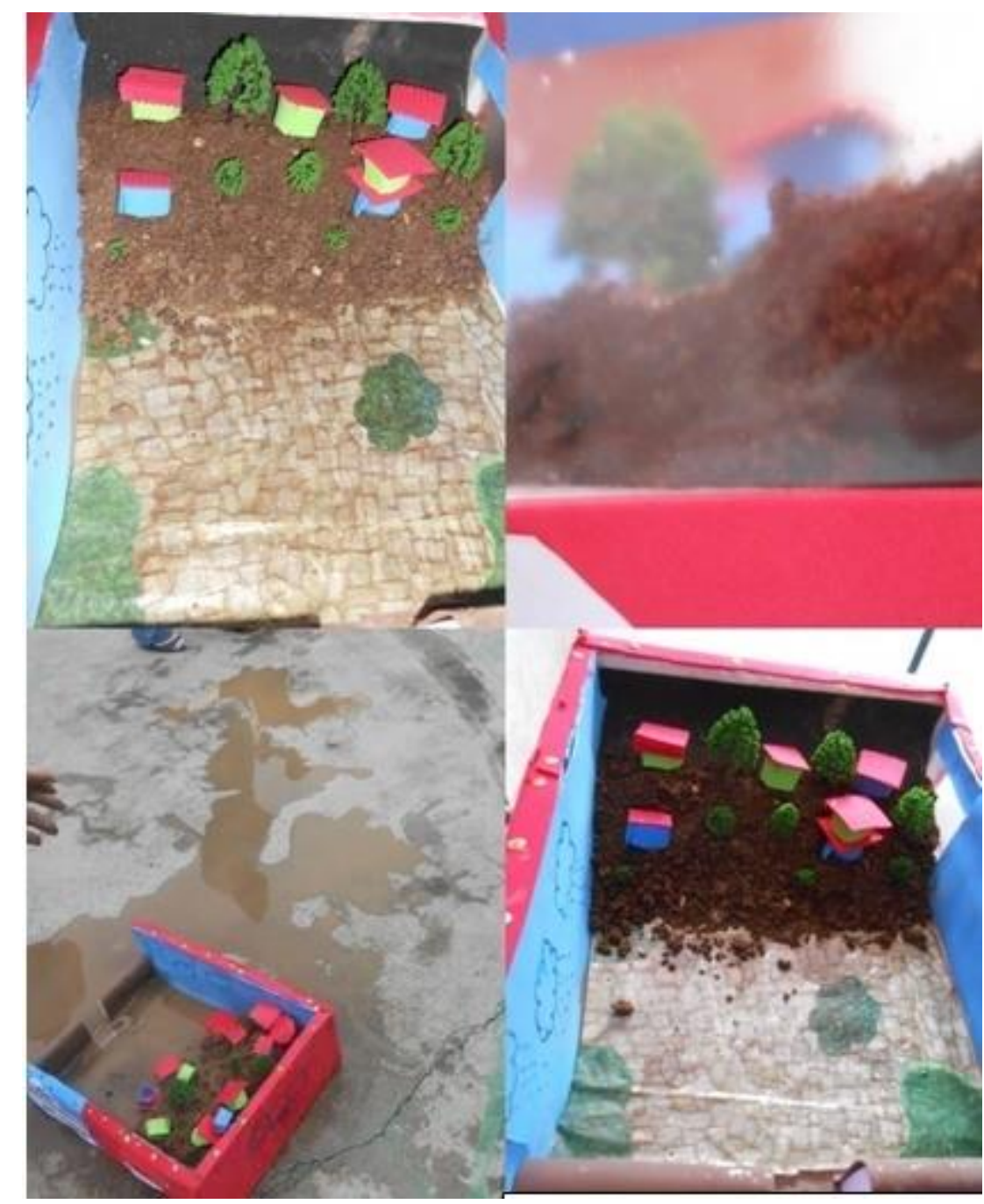

Fgura 5 - Maquete. Fonte: Cristiane O. Ferreira. Out. 2015.

Desta forma, pode-se indicar o efeito da chuva sob a encosta e as possíveis consequências da ocupação nestas áreas, como os desastres relacionados à erosão e também às enchentes que podem ocorrer devido ao assoreamento dos rios.

A partir deste momento, houve um debate sobre a vulnerabilidade ambiental e modos de convivência possíveis com os riscos, como a necessidade da vegetação na encosta e também a importância do respeito à Defesa Civil e seus sinais de alerta através das sirenes de evacuação das residências. Interessante destacar que muitos alunos expuseram não acreditar nos órgãos públicos, como a própria Defesa Civil que, desta forma, não atendia as suas exigências, como a evacuação das residências através das sirenes de alerta. Tal problemática, identificada ao longo da oficina, deverá ser foco de 
desdobramento desta pesquisa, buscando-se identificar as razões desse descrédito, bem como cientificar a própria Defesa Civil de modo que possa tomar as providências cabíveis frente a uma situação tão relevante para a proteção desta comunidade.

Ao final, os estudantes foram convidados a produzir cartazes sobre o que tinham compreendido da oficina, baseado num roteiro de perguntas: Como percebo o risco que está no meu entorno? Como conviver com ele? O que fazer para minimizá-lo?

Pode-se notar uma similaridade entre a maquete trabalhada e os desenhos feitos pelos estudantes nos cartazes, o que demonstra que esta metodologia diferenciada atraiu a atenção dos alunos e ajudou na compreensão da dinâmica dos movimentos de encosta em que um grupo esquematizou todo o processo, como destaca a figura 6.

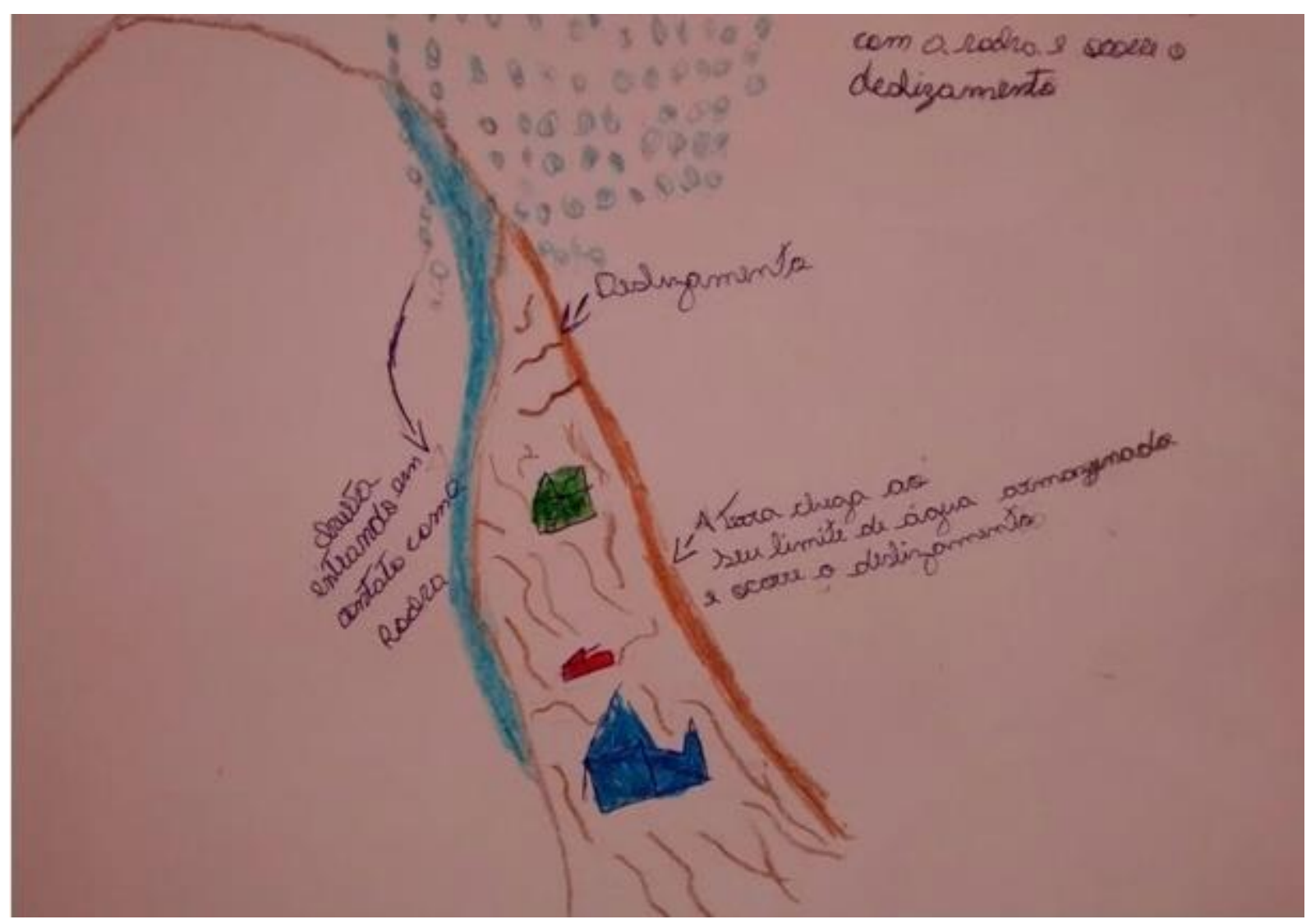

Figura 6 - Esquematização do processo dos movimentos de massa produzido pelos estudantes. Fonte: Cristiane O. Ferreira. Out. 2015. 
Outro fator interessante foram as respostas dadas às perguntas propostas, baseadas nos debates que ocorreram durante a oficina. Uma das questões levantadas pelos estudantes foi o fator financeiro para adquirir casas em locais seguros pelas suas famílias. Um dos grupos escreveu: "Se você mora em um local de risco e não tem condições financeiras para mudar, procure o ponto de apoio mais próximo" (figura 7).

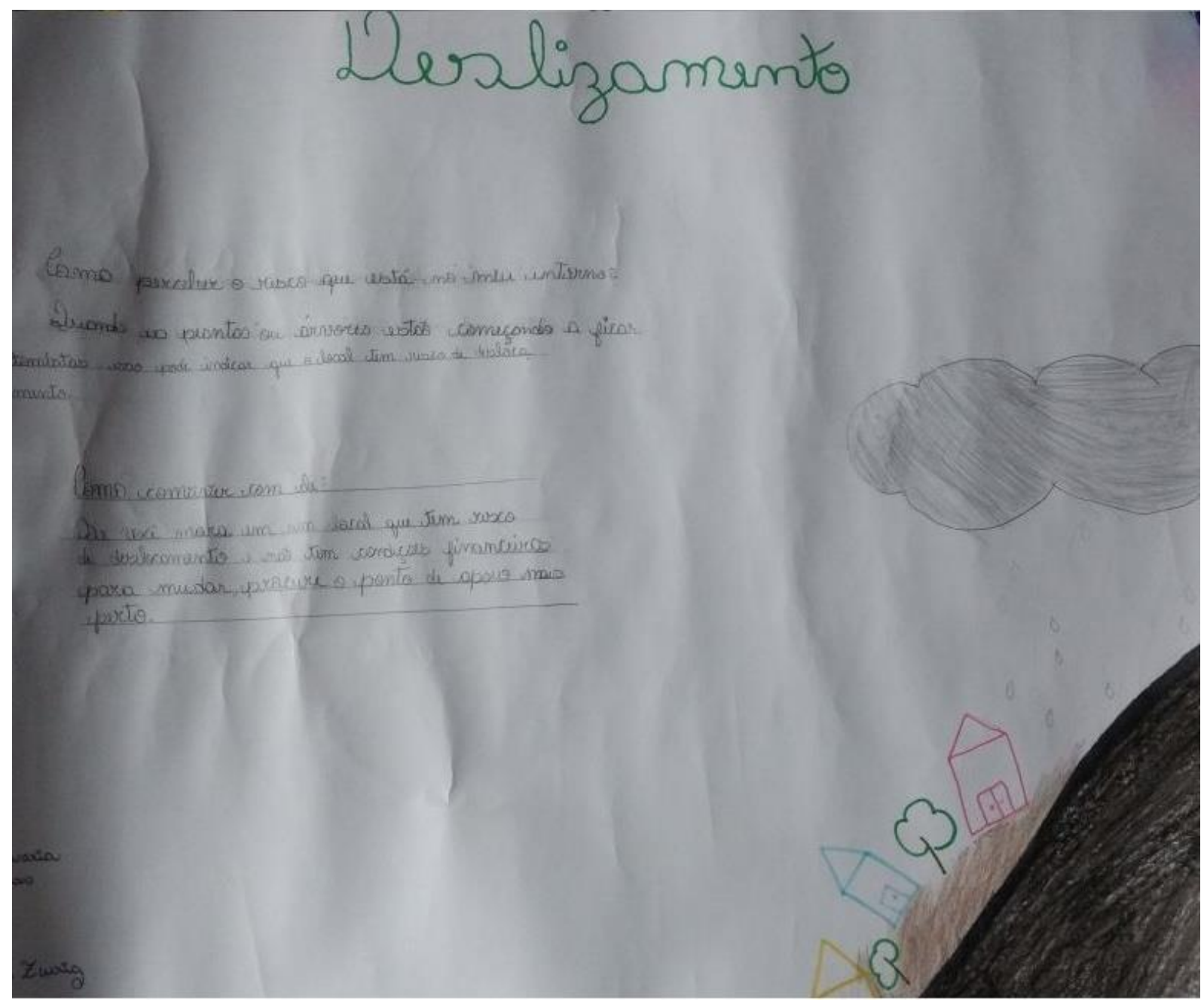

Figura 7 - Medidas para conviver com o risco. Fonte: Cristiane O. Ferreira. Out. 2015.

A oficina teve o intuito de ampliar o espaço de diálogo sobre o tema e de contribuir para o processo de ampliação e construção da percepção sobre os riscos por parte dos estudantes, o que pode ser crucial em uma situação de emergência, 
propiciando ações mais rápidas de proteção civil, como o refúgio em pontos de apoio. Como destaca um dos grupos ao responder a pergunta de como conviver com o risco: "De forma normal, mas consciente da área de convívio, saber a hora certa de sair de casa quando estiver chovendo e ir para o ponto de apoio mais próximo, com as coisas pessoais mais importantes como documentos." Pode-se observar este cartaz na figura 8.
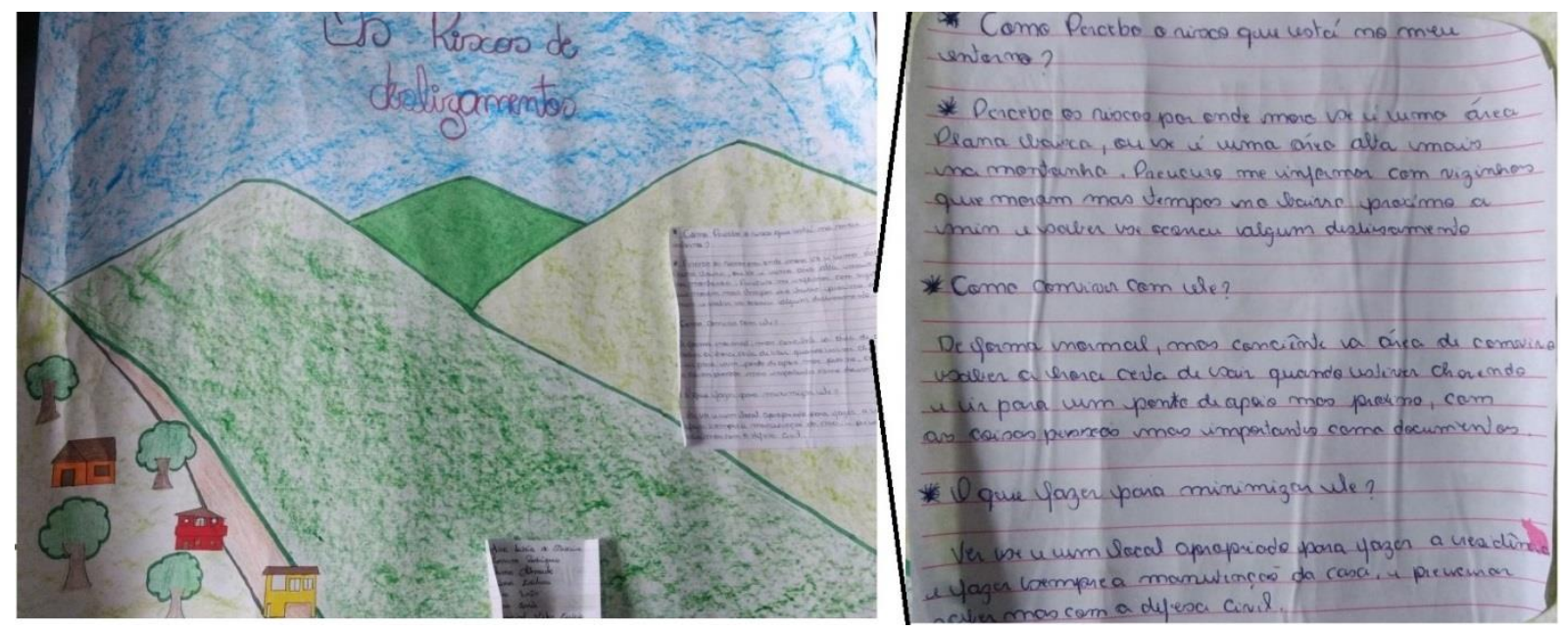

Figura 8 - Como conviver com os riscos. Fonte: Cristiane O. Ferreira. Out. 2015.

Na oficina, buscou-se inter-relacionar a educação ambiental com o eixo temático dos deslizamentos de terra e os princípios para a proteção civil, a fim de demonstrar a possibilidade de fazer esta união. Observou-se que os estudantes receberam de forma bastante positiva e participativa esta metodologia.

Apesar de ter sido uma iniciativa como fruto de uma pesquisa acadêmica dentro do ambiente escolar, esta atividade acabou sendo muito rica pela grande troca de conhecimentos entre os estudantes e as pesquisadoras, sendo avaliada positivamente pela professora de geografia envolvida e pela coordenação escolar. Estas responsáveis reiteraram a importância de atores externos se inserirem na realidade escolar, contribuindo para a disseminação dos conhecimentos relacionados aos desastres naturais.

Além disso, percebeu-se a necessidade de que haja maior enfoque no desenvolvimento de atividades voltadas para o público jovem. Estes são abertos a novas 
experiências no ambiente escolar e mostraram interesse em compreender a realidade local.

Infelizmente, muitas famílias são obrigadas a conviver com os riscos todos os dias em todo o território nacional, portanto é imprescindível que haja uma política efetiva de proteção destes indivíduos. Neste sentido, os princípios da educação ambiental crítica promovem as reflexões necessárias para a proteção da vida nas áreas de risco, contribuindo para o incremento de uma cultura de proteção civil.

Os conhecimentos geográficos podem ajudar nesta difícil tarefa, devido à compreensão dos riscos que envolvem a construção e ocupação desses ambientes inapropriados, sendo importantes para a compreensão da realidade da população inserida neste espaço e, ao mesmo tempo, para a busca de soluções dos problemas atuais. Tais saberes devem ser inseridos no processo de ensino e aprendizagem, uma vez que é necessário estimular o estudo e a reflexão sobre a segregação espacial, as desigualdades socioeconômicas e os riscos presentes na sociedade brasileira, visando à conquista da justiça ambiental.

\section{Considerações finais}

Petrópolis, localizada na região serrana do Rio de Janeiro, passou por grande transformação socioespacial com a industrialização nas décadas de 1940 e 1950, e, sua decadência. Atualmente, encontra-se com a economia voltada para o setor de serviços e turismo, havendo menos oferta de empregos em comparação com o passado industrial.

Assim, as consequências destas transformações acabaram recaindo sobre a população, cuja significativa parcela possui baixa renda e, como alternativa espacial para os problemas financeiros, construíram suas moradias, muitas vezes com infraestruturas precárias, nas encostas da Serra do Mar, sendo justamente as áreas mais vulneráveis.

Os movimentos de massa fazem parte da dinâmica natural deste ambiente, onde se encontra a município de Petrópolis, devido às suas características físicas como clima, relevo, solo, vegetação; porém, a construção de moradias aumenta os riscos de 
deslizamentos de terra sobre a população. É importante ressaltar que esta realidade não pode ser simplificada, e muito menos culpar os indivíduos que residem nestas áreas.

Esta situação é fruto da lógica capitalista de produção, em que as pessoas são vistas com mera mão de obra e sua segurança e bem estar não são considerados. Ao mesmo tempo, a apropriação capitalista do solo torna o capital como fator primordial para a habitação em áreas seguras. A parcela da população que possui melhores condições financeiras pode adquirir casas fora das áreas de maior risco do município, enquanto a maior parte da população é obrigada a conviver com os riscos ambientais, como enchentes e deslizamentos de terra.

A vulnerabilidade da população moradora de áreas de risco fica evidente quando analisados os dados socioeconômicos, demonstrando a baixa capacidade de prevenção, como a melhoria da infraestrutura das residências e de reação frente aos desastres, como compra de mantimentos ou aluguel de moradias seguras. Para agravar esta situação, o poder público também tem se mostrado ineficaz na proteção dos mais vulneráveis. Assim, evidencia-se em Petrópolis um quadro de injustiça ambiental sobre os moradores das áreas de risco.

Inserida nesta realidade complexa, encontra-se a Escola Municipal Stefan Zweig, onde a gestão e os discentes de uma turma do $9^{\circ}$ ano do ensino fundamental (2015) colaboraram para o desenvolvimento desta pesquisa, dando todo o suporte necessário para que esta pudesse ser realizada.

Isso demonstra o papel social que as escolas podem exercer diante dos problemas apresentados em seu entorno. Facilitando pesquisas, incentivando diálogos entre seus estudantes e diversos atores de fora da comunidade, como agentes de defesa civil e pesquisadores interessados em buscar melhorias para a comunidade.

Durante a oficina aplicada, os estudantes do $9^{\circ}$ ano se mostraram interessados com a temática apresentada e conforme foi se desenvolvendo a atividade eles expuseram inúmeras vivências, inclusive abordando inúmeros temas que não estavam planejados, como o valor das moradias mais seguras e a desconfiança que os alunos sentem em relação à defesa civil e os alertas de deslizamentos. 
Isso demonstrou que os estudantes possuem interesse em compreender melhor seu cotidiano e em serem ouvidos, portanto, estas trocas de conhecimentos também devem estar presentes na escola de forma contínua. Assim, a inquietação dos mesmos pode e deve ser utilizada, com auxílio da educação ambiental, na compreensão das interrelações dos diversos fatores que constroem a realidade complexa que envolve os movimentos de massa.

Desta forma, conclui-se que apenas as saídas pontuais e técnicas não são suficientes para a solução desta problemática complexa. É necessária maior aproximação com a comunidade envolvida visando compreender suas demandas e entendimentos a respeito do risco e a tornando agente no processo de redução de ameaças.

Neste contexto, a troca de saberes se torna essencial, abrangendo tanto os conhecimentos científicos como os populares, tanto dos professores como dos alunos, tanto da defesa civil como da comunidade. Através da pesquisa foi possível perceber que as escolas locais podem servir como pontes para troca de conhecimentos científicos e populares, contribuindo na busca de soluções para este problema socioambiental e na construção da cultura de proteção civil.

Assim, a educação ambiental crítica possui um papel importante diante das realidades de risco, pois compreende a inter-relação entre sociedade-natureza, ou seja, aspectos físicos e humanos que colaboram para o desenvolvimento dos desastres. Esta vertente educacional deve servir como embasamento para "reflexão sobre as desigualdades socioeconômicas e seus impactos ambientais, que recaem principalmente sobre os grupos vulneráveis, visando à conquista da justiça ambiental” (Brasil, 2012, p. 5).

Compreendendo que os sistemas de ensino são concebidos por seres humanos que possuem concepções próprias de ciência e do papel da escola, eles podem ser adaptados ou transformados por educadores que assumam a não neutralidade da educação e de seu papel social, com uma das forças na busca da transformação social, a fim de suprimir as injustiças sociais e ambientais.

Diante da complexidade do mundo contemporâneo e da realidade local, os educadores ambientais devem agir, principalmente, em duas frentes: no local imediato 
preparando os estudantes para agirem de forma adequada em situações de desastres, como os deslizamentos de terra; e no futuro possível, dando suporte para o conhecimento pleno da realidade atual nas diversas escalas, da local a global, para que sejam cidadãos críticos e atores na busca de um futuro mais seguro e igualitário.

\section{Referências}

ACSELRAD, Henri; HERCULANO, Selene; PÁDUA, José Augusto. A justiça ambiental e a dinâmica das lutas socioambientais no Brasil - uma Introdução. In: ACSELRAD, Henri; HERCULANO, Selene; PÁDUA, José Augusto (Orgs.). Justiça ambiental e cidadania. Rio de Janeiro: RelumeDumará, 2004.

\section{ALMEIDA, Lutiane Queiroz da. Riscos ambientais e vulnerabilidade nas cidades} brasileiras: Conceitos, metodologias e aplicações. São Paulo, sp: Cultura Acadêmica, 2012. 2012 p. Publicado pelo programa de Publicações Digitais da Pró-Reitoria de Pós Graduação da Universidade Estadual Paulista" Júlio de Mesquita Filho"(UNESP).

BECK, Ulrich. Sociedade de risco: rumo a uma outra modernidade. 2. ed. São Paulo: 34, 2011. 383 p. Tradução de Sebastião Nascimento.

\section{BRASIL. CENTRO NACIONAIS DE MONITORAMENTO E ALERTAS DE DESASTRES}

NATURAIS. Movimento de Massa. 2016. Disponível em:

<http://www.cemaden.gov.br/deslizamentos//>. Acesso em: 17 mar. 2017.

BRASIL. Ibama. Ministério do Meio Ambiente. Plano de manejo da área de proteção ambiental da Região Serrana de Petrópolis: Resumo Executivo. Petrópolis, [2005] BRASIL. Icmbio. Ministério do Meio Ambiente. Parque Nacional da Serra dos Orgãos: Clima. 2015. Disponível em <http://www.icmbio.gov.br/parnaserradosorgaos/atributos-naturais/45-clima.html>. Acesso em: 05 dez. 2015.

\section{BRASIL. INSTITUTO BRASILEIRO DE GEOGRAFIA E ESTATISTICA. Censo}

Demográfico 2010: Petrópolis. [s.l]: Ibge, 2010. Disponível em: <http://cod.ibge.gov.br/2334M >. Acesso em: 11 fev. 2015.

BRASIL. INSTITUTO BRASILEIRO DE GEOGRAFIA E ESTATÍSTICA. Cidades: Petrópolis. 2010. Disponível em:<http://cidades.ibge.gov.br/v3/cidades/municipio/3303906>. Acesso em: 10 jan. 2017. 
BRASIL. INSTITUTO BRASILEIRO DE GEOGRAFIA E ESTATÍSTICA. Conselho Nacional de Estatística. Sinopse estatística do município de Petrópolis: Estado do Rio de Janeiro. Rio de Janeiro: Serviço Gráfico do Instituto Brasileiro de Geografia e Estatística, 1948

BRASIL. Resolução Cne/cp 2. Diretrizes Curriculares Nacionais de Educação Ambiental. Brasília, 2012.

BRASIL. Secretaria Nacional de Proteção e Defesa Civil. Ministério da Integração Nacional. Sistema Integrado de Informações sobre Desastres - S2ID. 2017. Disponível em: <https://szid.mi.gov.br/paginas/relatorios/index.xhtml>. Acesso em: 16 mar. 2017.

CASTELLO BRANCO, Maria Luisa Gomes. Maria Luisa Gomes Castello Branco. A Dinâmica metropolitana, movimento pendular e forma urbana: o espaço urbano do Rio de Janeiro. In: ENCONTRO NACIONAL DE ESTUDOS POPULACIONAIS-ABEP. Caxambu.

Anais...Abep,2006. Disponível em:

<http://www.abep.nepo.unicamp.br/encontro2006/docspdf/ABEP2006_555.pdf>. Acesso em: 10 maio 2015.

CASTRO, Antônio Luiz Coimbra de. Manual de planejamento em defesa civil. Brasil: Imprensa Nacional, 1999. 1 v. Desenvolvido pelo ministério de integração nacional secretaria de defesa civil.

CORRÊA, Roberto Lobato. O espaço urbano. 4. ed. São Paulo: Atica, 200o. (Princípios)

DAGNINO, Ricardo de Sampaio; CARPI JUNIOR, Salvador. Risco Ambiental: Conceitos e Aplicações. Climatologia e Estudos da Paisagem, Rio Claro, v.2, n.2, p. 50 -87. jul/dez 12007.

FERREIRA, Cristiane Oliveira. Área de risco e justiça ambiental: contextualizando a realidade de Quitandinha/Petrópolis através da educação ambiental crítica. 2015. 77 f. TCC (Graduação) - Curso de Licenciatura Plena em Geografia, Departamento de Educação e Sociedade, Universidade Federal Rural do Rio de Janeiro - Instituto Multidisciplinar, Nova Iguaçu, 2015.

GALVANI, Emerson. Unidades climáticas brasileiras. São Paulo, 2014. Departamento de Geografia - USP. Disponível em:

<http://www.geografia.fflch.usp.br/graduacao/apoio/Apoio/Apoio_Emerson/Unidades_Cli maticas_Brasileiras.pdf>. Acesso em: 12 fev. 2014.

GOULD, Kenneth. Classe social, justiça ambiental e conflito político. In ACSELRAD, H.; HERCULANO, S.; PÁDUA, J.A.(Orgs). Justiça ambiental e cidadania. Rio de Janeiro: RelumeDumará: Fundação Ford, 2001. 
GREGÓRIO, Roberta dos Santos. Petrópolis-cidade imperial? da representação do espaço aos espaços de representação, 2014. Disponível em:

<observatoriogeograficoamericalatina.org.mx>. Acesso em: 7 de maio de 2014

GUERRA, Antonio José Teixeira; LOPES, Patrícia Batista Melo; SANTOS FILHO, Raphael David dos. Características geográficas e geomorfológica da APA Petrópolis, Rj. Revista Brasileira de Geomorfologia , v. 8, n. 1, p.77-86, 2007.

GUIMARÃES, Mauro. A formação de educadores ambientais. 4. ed. Campinas: Papirus, 2004. (Coleção Papirus Educação)

LAYRARGUES, Philippe Pomier; LIMA, Gustavo Ferreira da Costa. Mapeando as macrotendências político-pedagógicas da educação ambiental contemporânea no Brasil. In: ENCONTRO "PESQUISA EM EDUCAÇÃO AMBIENTAL", 6., 2011, Ribeirão Preto.

Anais...Ribeirão Preto: Epea, 2011. p. 1 - 15.

LIMA, Gileno Alves de. Ciclo de redução de riscos de desastres - RRD. Petrópolis, 2015. Apostila disponível para o curso $1^{\circ}$ Curso de Capacitação para Professores em Proteção e Defesa Civil, parte do Programa Escola Resiliente feita em parceria entre a Prefeitura de Petrópolis e a Secretaria de proteção e defesa civil.

PETRÓPOLIS, Secretaria de ciência e tecnologia, desenvolvimento econômico e agricultura. Guia do investidor. Rio de Janeiro, 2012.

RANDOLPH, Rainer. Utopia burguesa ou revolução urbana? : Transformações da organização territorial e novas formas urbanas em áreas peri-metropolitanas do Rio de Janeiro. In: ENCONTRO NACIONAL DA ASSOCIAÇÃO NACIONAL DE PÓSGRADUAÇÃO E PESQUISA EM PLANEJAMENTO URBANO E REGIONAL,XI, 2005, Salvador. Anais... Anpur, 2005. Disponível em:

<http://unuhospedagem.com.br/revista/rbeur/index.php/anais/article/view/2670>. Acesso em: 10 maio 2015 .

RIO DE JANEIRO. Secretaria geral de planejamento. Estudos socioeconômicos dos municípios do Estado do Rio de Janeiro: Petrópolis. Rio de Janeiro: TCE-RJ, 2013.

REDE BRASILEIRA DE JUSTIÇA AMBIENTAL. Manifesto de lançamento da Rede Brasileira de Justiça Ambiental. 2001. Disponível em: http://www.justicaambiental.org.br . Acesso em: 13 maio 2014

SANTOS, Rozely Ferreira dos; CALDEYRO, Verônica Sabatino. Paisagens, Condicionantes E Mudanças. In: SANTOS, Rozely Ferreira dos. Vulnerabilidade ambiental. Brasília: MMA, 2007. p. 13-21. 
THEOPRATIQUE (Petrópolis). Plano Municipal de Riscos: $1^{\circ}$ Distrito de Petrópolis, Rj. Petrópolis, 2007.

TOMINAGA, Lidia Keiko; Santoro, Jair.; Amaral, Rosangela do (Org), Desastres naturais: conhecer para prevenir. São Paulo: Instituto Geológico, 2015.

TRISTÃO, Martha. As dimensões e os desafios da educação ambiental na sociedade do conhecimento. In: RUSHEINSKY, A. (Orgs.). Educação ambiental: abordagens múltiplas. p.169-183. Porto Alegre: Artmed, 2002.

UNIVERSIDADE FEDERAL DE SANTA CATARINA. Centro Universitário de Estudos e Pesquisas sobre Desastres.,. Atlas brasileiro de desastres naturais 1991 a 2010: Volume Brasil. Florianópolis:CEPED/UFSC 94 p. 2012.

UNIVERSIDADE FEDERAL DE SANTA CATARINA. Centro Universitário de Estudos e Pesquisas sobre Desastres.Atlas brasileiro de desastres naturais 1991 a 2010: Volume Rio de Janeiro. Florianópolis: CEPED/UFSC. 63 p. 2012.

UNITED NATIONS DEVELOPMENT PROGRAMME. Reducing Disaster Risk: a Challenge for Development. UNDP, 2012

http://www.undp.org/content/undp/en/home/librarypage/crisis-prevention-andrecovery/reducing-disaster-risk--a-challenge-for-development.html. Consulta realizada em 7 de maio de 2017

VALENCIO, Norma; SIENA, Mariana; MARCHIZINI, Victor. Maquetes interativas: Fundamentos teóricos, metodológicos e experiências de aplicação. In: VALENCIO, Norma et al. (Orgs.). Sociologia dos desastres: construção, interfaces e perspectivas no Brasil. São Carlos: Rima Editora, 2009. p. 199-215. 